\title{
EFFECTIVENESS OF STUDENT WORKSHEET ORIENTED ON THE GUIDED DISCOVERY LEARNING USING MIND MAPPING TO FACILITATE STUDENTS' SCIENCE PROCESS SKILLS
}

\author{
Oleh: \\ Lathifatuz Zuhriyah, Wahono Widodo \\ Program Studi Pendidikan IPA, FMIPA, Universitas Negeri Surabaya \\ wahonowidodo@unesa.ac.id
}

\begin{abstract}
This study aims to describe the effectiveness of student worksheet oriented on the guided discovery learning using mind mapping to facilitate student's science process skills. The data collection method was obtained from the test method with the type of one group pretest posttest design research. The study was conducted in class VIII-B MTsN Gresik with 30 students. The results showed as many as 27 students received n-gain scores in the high category and 3 students received n-gain scores in the medium category. In this study, it can be concluded that the student worksheet oriented guided discovery learning uses mind mapping to facilitate students' science process skills declared feasible in terms of effectiveness based on the science process skills test data, each student has a high category and the improvement science process skills indicator data that has a high category.

Kata Kunci: worksheet, guided discovery, mind mapping, science process skills
\end{abstract}

\section{Introduction}

Natural Science is a systematic theories, where the general implementation is limited to the natural phenomenon, born and develop through the scientific method including observation and experiment as well as require scientific manner like curiosity, open minded, honesty and etc (Purwasari, 2013). Fundamentally, natural science develops some adaptive competencies that deals with the current changes to the future condition. One of competencies that relates to natural science is the science process skills.

Science process skills is one of advanced thinking skills that invites the student to be active learner in doing analysis, evaluation and creation (Conklin, 2012). If the student is used to the science process skills, so the student will realize and pay more attention to the knowledge, and the process to achieve the study goal. Semiawan (1992) stated that the science process skills is an activator for students to develop a concept. Training science process skills will give direct experience to the students in developing a concept and implementing it to solve problem in the dialy life to face the future challenge.

In 2015, the focused theme used by PISA is science competency test using some elements of science process skills. Based on the test result and PISA survey in 2015 involving 540,000 students shows that Indonesian students' performance is relatively low. Indonesia is in the 62 position out of 72 countries being evaluated. This result proves that Indonesian's science process skills is quite low.

Science process skills is crucial need for the students as the preparation and practice to deal with the real social life since the student are trained to think logically to solve a problem. One thing to cope with lower science process skills is providing a certain learning model to help the students to obtain new experiences directly. The learning model that is suitable to help the student in achieving new direct experience is guided discovery model. Guided discovery model will ease the students to understand learning material. According to Sani \& Ridwan (2014), guided discovery learning is one of learning models that requires the students to discover a concept by the teacher's creative guidance during a class preparation.

Guided discovery learning and mind mapping strategy collaboration to train students' science process skills is used to build students' understanding on science process skills indicator. After the students teamed up to build their knowlege through experiment activity based on guided discovery learning, the students are directed individually to reconstruct information or ideas obtained from the mind mapping making. 
In this study, to train the students' science process skills is needed to use learning sources that can support learning activity. Jailani and Hamid (2016) stated that, the existence of learning source is crucial for learning activity so that every teacher is required to build up the learning sources. Learning sources are expected to be innovative, varieties, interesting, contextual and agrees with students' needs. One of teaching materials that can be obliged as the guidance in implementing practical activity to train the students' science process skills is student worksheet.

Rooted from the above explanation, the researcher is interested to do observation entitled an effectivity of worksheet oriented on the guided discovery learning using mind mapping to train students' science process skills.

\section{Research Method}

The object of this study are 30 students of VII-B MTSN Gresik. The type of research is One Group Pre-Test And Post-Test Design.

Table 1. Experiment Design

\begin{tabular}{ccc}
\hline Pre-test & Treatment & Post-test \\
\hline $\mathrm{O}_{1}$ & $\mathrm{X}$ & $\mathrm{O}_{2}$ \\
\hline
\end{tabular}

(Sugiyono, 2014)

The improvement of student science process skills through providing pre-test and post-test can be measured by using n-gain formulla as follows:

$$
\left\langle\mathrm{g}>=\frac{S_{\text {posttest }}-S_{\text {pretest }}}{S_{\text {max }}-S_{\text {pretest }}}\right.
$$

Notes :

$$
\begin{array}{ll}
\langle\mathrm{g}\rangle & =\mathrm{N}-\text { Gain score } \\
\mathrm{S}_{\text {pretest }} & =\text { pre-test score } \\
\mathrm{S}_{\text {postest }} & =\text { post-testscore } \\
\mathrm{S}_{\max } & =\text { maximum score }
\end{array}
$$

Then the normalized gain is interpreted according to the following criteria:

Table 2. Gain Criteria Normalized

\begin{tabular}{cc}
\hline$<\mathrm{g}>$ & Criteria \\
\hline $0,70<\mathrm{g} \leq 1,00$ & High \\
$0,30<\mathrm{g} \leq 0,70$ & Medium \\
$0,00<\mathrm{g} \leq 0,30$ & Low \\
\hline
\end{tabular}

(Hake,2002)

Based on these criteria, the interactive digital module was declared to be effective for improving student learning outcomes if student learning outcomes obtained a gain score of $>0.3$ with medium and high criteria.

\section{Result}

An appropriateness of worksheet development is based on the effectiveness aspect gained from pretest and post-test result. Pre-test result and post-test result are used to examine the improvement of students' science process skills. The improvement of science process skills is reviewed by the equation of n-gain (Hake, 2002). N-gain is used to determine how much the improvement of students' science process skills after conducting experiment using developed LKS.

The result of pretest and posttest score can be seen in Table 3 .

Table 3. Analysis Pretest-Posttest Score

\begin{tabular}{ccccc}
\hline Student & Pretest & Posttest & N-Gain & Criteria \\
\hline 1 & 10 & 90 & 0,9 & High \\
2 & 40 & 95 & 0,9 & High \\
3 & 55 & 95 & 0,9 & High \\
4 & 25 & 95 & 0,9 & High \\
5 & 30 & 90 & 0,9 & High \\
6 & 10 & 95 & 0,9 & High \\
7 & 20 & 95 & 0,9 & High \\
8 & 25 & 95 & 0,9 & High \\
9 & 40 & 100 & 1,0 & High \\
10 & 20 & 90 & 0,9 & High \\
11 & 35 & 90 & 0,8 & High \\
12 & 45 & 95 & 0,9 & High \\
13 & 45 & 90 & 0,8 & High \\
14 & 30 & 90 & 0,9 & High \\
15 & 25 & 80 & 0,7 & Medium \\
16 & 40 & 85 & 0,8 & High \\
17 & 15 & 90 & 0,9 & High \\
18 & 30 & 90 & 0,9 & High \\
19 & 45 & 100 & 1,0 & High \\
20 & 15 & 95 & 0,9 & High \\
21 & 40 & 85 & 0,8 & High \\
22 & 50 & 85 & 0,7 & Medium \\
23 & 45 & 90 & 0,8 & High \\
24 & 40 & 95 & 0,9 & High \\
25 & 50 & 95 & 0,9 & High \\
26 & 25 & 95 & 0,9 & High \\
27 & 40 & 90 & 0,8 & High \\
28 & 35 & 90 & 0,8 & High \\
29 & 35 & 80 & 0,7 & Medium \\
30 & 10 & 95 & 0,9 & High \\
\hline & & & & \\
\hline
\end{tabular}

Based on the n-gain result obtained by each student, it is found that the average n-gain is 0.9 in the high category. The total students that experience improvement in the high category are 27 students while there are 3 students categorized to have moderate improvement.

\section{N-Gain score category for Science Process Skills Of Grade VIII-B Students at MTsN Gresik}

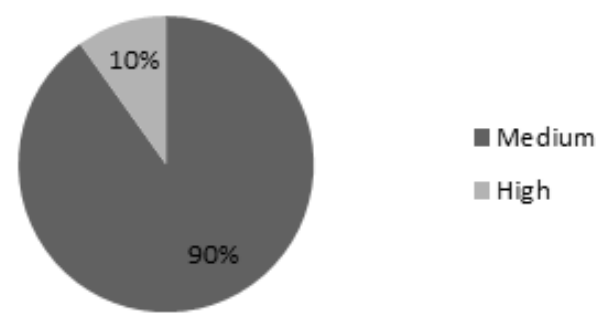


Figure 1. Diagram of Average Precentage N-gain

Score of The Student's Science Process Skills

The result relates to the guided discovery learning model and mind mapping strategy as an action. Syah in Abidin (2014) declares that guided discovery learning has some syntaxes namely stimulation, problem statement, data collection, data processing, verification, andgeneralization.

The syntaxes have similarity with some science process skills so that this learning model can ease the students to understand the material and improve the science process skills. Otherwise, guided discovery learning process also provides a chance for the students to develop active thinking by doing self-discovery and observation. Hence the result will be durable in the memory (Hosnan, 2014). This is also supported by Astuti's research (2019) that the discovery learning can improve students' science process skills that increase the precentage significantly.

The improvement of science process skills cannot be separated from the application of mind mapping strategy, where this strategy helps the students to creatively understand, remember, and develop their science process skills indicators to be knowledge and action (Suciati, 2016). Providing mind mapping strategy in the end of lesson will improve students' understanding on the obtained information especially science process skills indicator. This strategy contributes to give a chance for the students to reconstruct the learning process they have achieved individually. Buzan (2012) stated that, mind map is the easiest way to process information in the brain and ease the students to understand and remember certain information. This is also supported by Prastiwi, Haryani\&Lisdiana (2018), that inquiry based learning using mind map technique can improve the students' science.

Table 4. Improved Indicators on Student Science Process Skills

\begin{tabular}{|c|l|c|c|c|c|}
\hline \multirow{2}{*}{$\begin{array}{c}\text { N } \\
\mathbf{o}\end{array}$} & $\begin{array}{c}\text { Indicator of } \\
\text { Science } \\
\text { Process Skills }\end{array}$ & \multicolumn{2}{|c|}{ Percentage (\%) } & N-gain & Category \\
\cline { 2 - 6 } 1 & $\begin{array}{l}\text { Formulate } \\
\text { problem }\end{array}$ & 3,67 & 19,00 & 0,9 & High \\
\hline 2 & $\begin{array}{l}\text { Formulate } \\
\text { Hypothesis }\end{array}$ & 3,33 & 18,83 & 0,9 & High \\
\hline 3 & $\begin{array}{l}\text { Identifying } \\
\text { variables }\end{array}$ & 6,00 & 15,00 & 1,0 & High \\
\hline 4 & $\begin{array}{l}\text { Analyzing } \\
\text { Data }\end{array}$ & 8,67 & 12,33 & 0,6 & Medium \\
\hline 5 & Conclude & 6,00 & 14,33 & 0,9 & High \\
\hline 6 & Communicate & 4,67 & 12,17 & 0,7 & Medium \\
\hline
\end{tabular}

\section{Improvement of Science Process Skill Indicators}

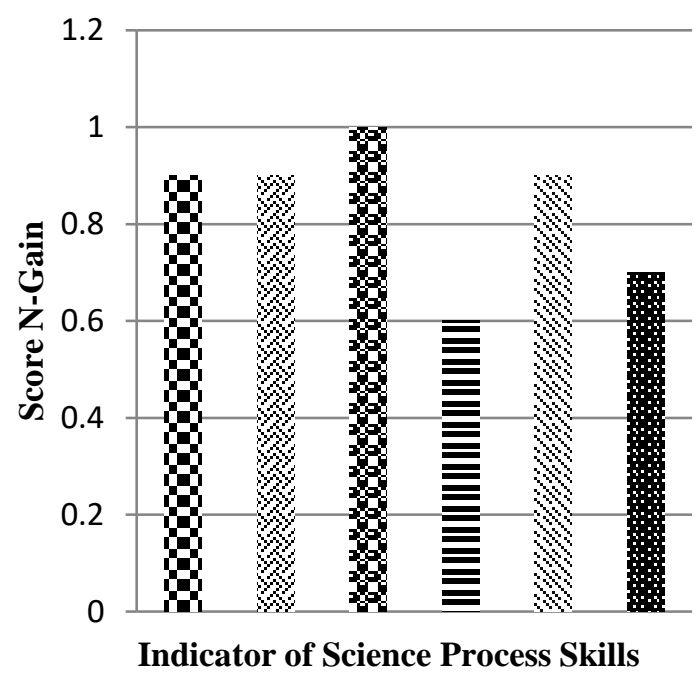

$\begin{array}{ll}\text { Note : } & \\ & =\text { Formulate problem } \\ & =\text { Formulate Hypothesis } \\ & =\text { Identifying variables } \\ & =\text { Conalyzing Data } \\ & =\text { Communicate }\end{array}$

Figure 2. Diagram of Science Process Skill Indicators

Apart from improving the science process skills of each student, it can also be seen the improvement of each indicator of science process skills. The results of improving each aspect of science process skills obtained an average percentage of n-gain of 0.8 with a high category. In the aspect of skill formulating the problem obtaining an n-gain score of $0.9 \%$ included in the high category, formulating a hypothesis of $0.9 \%$ included in the high category, identifying variables by $1.0 \%$ included in the high category, analyzing data by $0.6 \%$ included in the medium category, concluded by $0.9 \%$ included in the high category, and communicating by $0.7 \%$ included in the medium category. Based on these results, it is known in the aspects of formulating the problem, formulating hypotheses, identifying variables and concluding an increase in high n-gain. While in the aspect of analyzing data and communicating a moderate increase in n-gain is obtained.

That is because although all indicators of science process skills have been explained at the beginning of learning, not all indicators can show the same amount of improvement because the increase using the n-gain equation takes into account the students 'initial and final abilities, 
when students' initial abilities are high then a significant increase will be difficult occur. Another thing that affects the acquisition of $n$-gain scores on indicators analyzing data that is still relatively low is the implementation of mind mapping where overall mind mapping that has been made by students has led to several indicators of science process skills that have been taught but the indicators of analyzing data are still Not yet seen from the mind mapping made by students during the three meetings, this is what is lacking and causes an increase in one of the science process skill indicators that is analyzing data is still relatively low.

The result shows that there is improvement on the student science process skills for high and moderate value. It caused by the learning process contains science process skills as a new program for the student that has been trained in 3 meetings. Although, most of the science process skills aspects which have been trained previously can improve into high category. The result shows that the students' process skills can be trained after the student worksheet developed. This is also supported by Mafania's research (2018) where it shows that student worksheet can improve the science process skills and are feseable based on the effectiveness aspect observed through the result of pre-test and post-test which shows $89 \%$ of student success in the post-test.

\section{Conclusion}

This research are concluded as follows :

Student worksheet oriented by guided discovery learning using mind mapping to train students' science process skills is considered effectively applicable based on the data of science process skill. The science process skill test of every each has a high category and the improvement science process skills indicator data that has a high category.

\section{SUGGESTION}

The suggestion for the better research is :

For further research, there should be a worksheet to train students 'skills with other material, it is hoped that through this habituation can improve students' process skills.

\section{REFERENCES}

Abidin, Y. 2014. Desain Sistem Pembelajaran dalam Konteks Kurikulum 2013. Bandung: Refika Aditama.

Astuti, Y. 2019. Improving Grade 9 Science Process Skills of SMPN 5 Probolinggo
Using Discovery Learning Model. JPPIPA, 4 (1).

Bala, R. 2018. Creative Teaching Mengajar Mengikuti Kemauan Otak. Jakarta: PT. Grasindo.

Buzan, T. 2012. Buku Pintar Mind Map. Jakarta: Gramedia Pustaka Utama

Conklin, W. 2012. Higher-Order Thinking Skills. Huntington Beach: Shell Educational Publishing.

Hake, R.R. 2002. Analyzing Change/Gain Score. Retrieve from http://www.physics.indiana.edu/sdi. Analizing Change-Gain.pdf

Hosnan. 2014. Pendekatan Saintifik dan Kontekstual dalam Pembelajaran Abad 21. Bogor: Ghalia Indonesia.

Jailani, M. S, \& Hamid, A. 2016. Pengembangan Sumber Belajar Berbasis Karakter Siswa. Jurnal Pendidikan Islam, 10 (2).

Sani, A \& Ridwan. 2014. Pembelajaran Saintifik untuk Implementasi Kurikulum 2013. Jakarta: Bumi Aksara.

Semiawan, C. 1992. Pendekatan Keterampilan Proses. Jakarta: Gramedia Widiasarana Indonesia

Suciati, D, I. 2016. Keefektifan Model Mind Mapping Pada Pembelajaran IPA Siswa Kelas IV SD Negeri Gugus Dworowati Semarang. Retrieve from https://lib.unnes.ac.id/29274/1/1401412219 . $\mathrm{pdf}$

Sugiyono. 2014. Metode Penelitian Kuantitatif, Kualitatid dan $R \& D$. Bandung: Alfabeta.

Mafania, Z, Q. 2018. Keefektifan lembar kegiatan siswa (LKS) berbasis discovery learning untuk meningkatkan keterampilan proses sains siswa. Thesis, Unpublished.

Prastiwi D, Haryani, S \& Lisdian. 2018. The Effectiveness of Guided Inquiry with Mind Mapping to Improve Science Process Skills and Learning Motivation. Journal of Primary Education. JPE 7 (2), 195 - 203.

Purwasari, Y. 2013. Meningkatkan Hasil Belajar IPA Tentang Perubahan Kenampakkan Permukaan Bumi dan Benda Langit Melalui Peta Pikiran Pada Anak Kesulitan Belajar Kelas IV SD 13 Balai-Balai Kota Padang Panjang. Jurnal Ilmiah Pendidikan Khusus. 1 (1), 536-548. 